\title{
A review of the infectious agents, parasites, pathogens and commensals of European cockles (Cerastoderma edule and C. glaucum) - ERRATUM
}

MATT LONGSHAW AND SHELAGH K. MALHAM

doi: 10.1017/Soo25315412000537, Published by Cambridge University Press, 30 August 2012

In the above article by M. Longshaw et al., first published online on 30 August 2012, the copyright line was incorrect. The correct copyright line appears below:

(C) Crown Copyright, 2012

First published online 11 February 2013 